\begin{tabular}{|c|c|c|c|c|c|}
\hline Z. Geomorph. N. F. & 43 & 4 & $417-438$ & Berlin - Stuttgart & Dezember 1999 \\
\hline
\end{tabular}

\title{
Late Miocene paleo-geomorphology of the Bakony-Balaton Highland Volcanic Field (Hungary) using physical volcanology data
}

\author{
by \\ Károly NÉmeth and UlRike Martin \\ with 10 figures and 3 tables
}

\begin{abstract}
Summary. A new view is presented of the Bakony-Balaton Highland Volcanic Field (BBHVF), Hungary, active in late Miocene and built up of ca. 100 mostly alkaline basaltic eruptive centers, scoria cones, tuff rings, maar volcanic complexes and shield volcanoes. A detailed map shows the physical volcanology of the monogenetic volcanic field. In areas where thick Pannonian Sandstone beds build up the pre-volcanic strata normal maar volcanic centers have formed with usually thick late magmatic infill in the maar basins. In areas, where relatively thin Pannonian Sandstone beds resting on thick Mesozoic or Paleozoic fracturecontrolled, karstwater-bearing aquifer, large unusual maar volcanic sequences appear (Tihany type maar volcanoes). In the northern part of the field large former scoria cones and shield volcanoes give evidence for a smaller impact of the ground and surface water causing phreatomagmatic explosive activity. The Tihany type maar volcanic centers are usually filled by thick maar lake deposits, building up Gilbert type gravelly, scoria rich deltas in the northern side of the maar basins, suggesting a mostly north to south fluvial system in the pre-volcanic surface. Calculating paleosurface elevation for the eruptive centers, two paleo-geomorphology maps are drawn for a younger (4-2.8 Ma) and an older (7.54-4 Ma) scenario. The erosion rate of the volcanic field is estimated to vary between $96 \mathrm{~m} / \mathrm{Ma}$ and $18 \mathrm{~m} / \mathrm{Ma}$. In the western site of BBHVF the erosion rate is higher (more than $60 \mathrm{~m} / \mathrm{Ma}$, Tapolca Basin), and an average $50 \mathrm{~m} / \mathrm{Ma}$ in the center and eastern side.
\end{abstract}

Zusammenfassung. Palaeographie des vulkanischen Gebietes im Bakony-Balaton-Hügelland (Ungarn, Obermiozän), belegt durch physikalisch-vulkanologische Daten. - Das vulkanische Gebiet im Bakony-Balaton-Hügelland in Ungarn war im Oberen Miozaen aktiv und umfaßt ca. 100, vor allem alkalin-basaltische, eruptive Zentren, Schlackenkegel, Tuffringe, Maar-Komplexe und Schildvulkane. Neue Ergebnisse erlaubten die Erstellung einer detaillierten physisch-vulkanologischen Karte, die ein monogenetisch vulkanologisches Gebiet zeigt. Wo Pannonische Sandsteine die pre-vulkanische Stratigraphie bilden, haben sich normale vulkanische Zentren gebildet, mit gewöhnlich mächtigen spätmagmatischen Ablagerungen in Maar-Kratern. In Gebieten, die weniger mächtige Panonische Sandsteinschichten über mächtigen Mesozoischen oder Palaeozoischen Karstwasser-führenden Aquiferen aufweisen, erscheinen ungewöhnliche vulkaniklastische Sequenzen (Tihany-Typ Maar-Vulkane). Im nördlichen Teil des Gebietes findet man große Schlackenkegel und Schildvulkane, die daraufhin deuten, daß der Einfluß von Grund- und Oberflächenwasser nicht gegeben war, der phreatomagmatische Explosionen ausgelöst haben könnte. Tihany-Typ Maar-Krater sind gewöhnlich gefüllt mit mächtigen Seeablagerungen, die im nördlichen Teil oft Gilbert-Typ-Deltas bil- 
den und reich an Schlacken sind, was darauf hindeutet, daß das ehemalige pre-vulkanische Gebiet geprägt war durch ein nord-südliches Fluß-System. Die Berechnung der Palaeohöhe ermöglichte es, zwei palaeo-geomorphologische Karten zu erstellen, die einerseits ein jüngeres (4-2.8 MA) und andererseits ein älteres (7.54-4 MA) Ereignungsbild darstellen. Die Erosionsrate wurde geschätzt und liegt wahrscheinlich zwischen $96 \mathrm{~m} / \mathrm{MA}$ und $18 \mathrm{~m} / \mathrm{MA}$. Im Westen des Arbeitgebietes liegt die Erosionsrate höher (mehr als $60 \mathrm{~m} / \mathrm{MA}$ ), im Zentrum und Osten liegt der Durchschnitt bei ca. $50 \mathrm{~m} / \mathrm{MA}$.

Résumé. Paléo-géomorphologie de la zone volcanique baute Bakony-Balaton (Hongrie), en utilisant des données de volcanologie physique. - Un nouveau regard est porté sur la zone volcanique haute Bakony-Balaton (Bakony-Balaton Highland Volcanic Field - BBHVF), Hongrie, active au miocène tardif et composée d'une centaine de centres éruptifs en majorité basaltiques alcalins, cônes de scories, anneaux de tuff, complexes volcaniques de maar et volcans boucliers. Une carte détaillée montre la volcanologie physique du terrain volcanique monogénétique. Dans les zones ou la couche pré-volcanique se compose d'épais lits de grès Pannoniens, des centres volcaniques normaux de type maar se sont formés avec des remplissages magmatiques tardifs généralement épais dans les bassins de maars. Dans les zones ou des lits de grès Pannoniens relativement fins reposent sur d'épais aquifères Mésozoiques ou Paléozoiques controlés par les fractures et contenant des eaux karstiques, apparaissent des séquences volcaniques de maars, inhabituelles et étendues (maar de type Tihany). Dans la partie Nord du terrain, d'anciens grands cônes de scories et des volcans boucliers impliquent un moindre impact des nappes phréatiques et eaux de surface causant une activité phréatomagmatique explosive. Les maars de type Tihany sont en général remplis par d'épais dépôts de lacs de maars, édifiant des deltas de type Gilbert, caillouteux, riches en scories, du côté Nord des bassins de maars, suggérant un système fluvial principalement Nord-Sud au niveau de la surface pré-volcanique. En calculant l'élévation de la paléosurface pour les centres éruptifs, deux cartes paléo-géomorphologiques sont tracées pour un scénario jeune (4-2.8 Ma) et un scénario ancien $(7.54-4 \mathrm{Ma})$. Le taux d'érosion du terrain volcanique varie, selon estimation, entre $96 \mathrm{~m} / \mathrm{Ma}$ et $18 \mathrm{~m} / \mathrm{Ma}$. Au niveau du site ouest du BBHVF, le taux d'érosion est plus important (plus de $60 \mathrm{~m} / \mathrm{Ma}$, Bassin Tapolca), et est d'une moyenne de $50 \mathrm{~m} / \mathrm{Ma}$ au centre et sur le côté est.

\section{Introduction}

The Bakony-Balaton Highland Volcanic Field (BBHVF) is located in the Central Pannonian Basin, Hungary and extends from the Keszthely Mts. in the west to the southernmost slopes of the High Bakony Mts. in the east. The region is right next to the north shore of Lake Balaton. The volcanic centers of the BBHVF were active approximately between $7.54 \mathrm{Ma}$ and $2.8 \mathrm{Ma}$ (BALOGH et al. 1982, 1986, BALOGH 1995, BORSY et al. 1986) (fig. 1.) and produced mostly alkaline basalt (e.g., SzaBó et al. 1992). The volcanism was related to the post-extensional tectonic processes in the central Pannonian Basin (SzaBó et al. 1992). They most likely represent a continuous facies between shallow water, emergent and subaerial hydrovolcanic processes in a large lacustrine-fluvial basin. The general paleo-environment and its hydrogeology caused a special kind of eruptive mechanism mainly in the explosive volcanic activity.

The BBHVF has more than 50 basaltic volcanoes (Lóczy 1913, Jugovics 1968, JÁMBOR et al. 1981), but this number seems to be strongly underestimated as several very complex eruptive centers are composed of a number of individual vents. The real number of eruptive centers could reach 150-200 in this relatively small (ca. $3500 \mathrm{~km}^{2}$ ) 


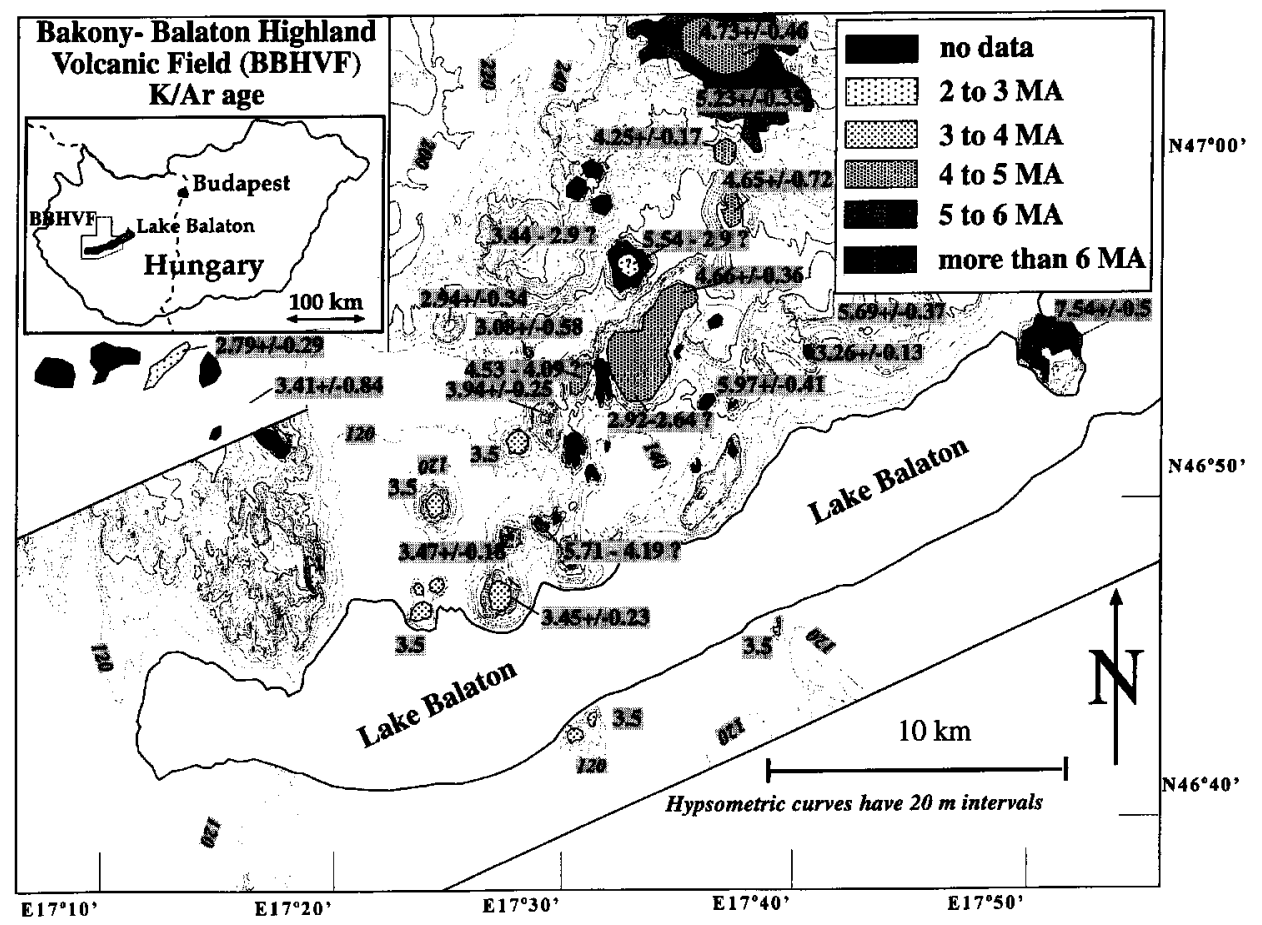

Fig. 1. Map with the K/Ar age (data from BALOGH et al. 1986, BorsY et al. 1986).

area (fig. 2.). The volcanic field belongs to the Transdanubian Central Range unit, which is correlated with the Upper Austroalpine nappes of the Eastern Alps (e.g. MAJOROs 1980, TARI 1994). The underlying basement of the volcanic field consists of thick Silurian schist, Permian Red Sandstone and Mesozoic carbonate beds. This unit basically forms a large scale anticline structure, which is locally covered by Tertiary sediments in local basins. The Silurian schist formation is a $400-600 \mathrm{~m}$ thick unit which contains alternating, very low-grade metamorphosed psammitic and pelitic beds (Lelkes-Felvári 1978). The Permian Red Sandstone Formation is a thick (400-600 m) continental alluvial formation (MAjoros 1980). The Mesozoic formations are represented by Triassic limestone and dolomites, which have a direct relation to the Triassic Eastern Alps. The younger sediments were deposited on an erosion surface in local sedimentary basins. In the Neogene, just shortly before the volcanism started, a large lake occupied the Pannonian Basin, the Pannonian Lake, with diverse sedimentary environments adjusted to the irregular basin morphology (KázMÉR 1990). The lacustrine sandstones, mudstones, marl of the brackish Pannonian Lake are widespread in the Pannonian Basin (KÁzMÉR 1990). These are usually finegrained clastic quartzofeldspathic sediments showing gradual transition into fine grained sandstones which were deposited in a shallower water environment. Just before volcanism started the area was most likely characterized by an alluvial plain with quick depositional changes within short distances (KÁzMÉR 1990). The volcanism was mainly subaerial but there is evidence of local subaqueous to emergent con- 


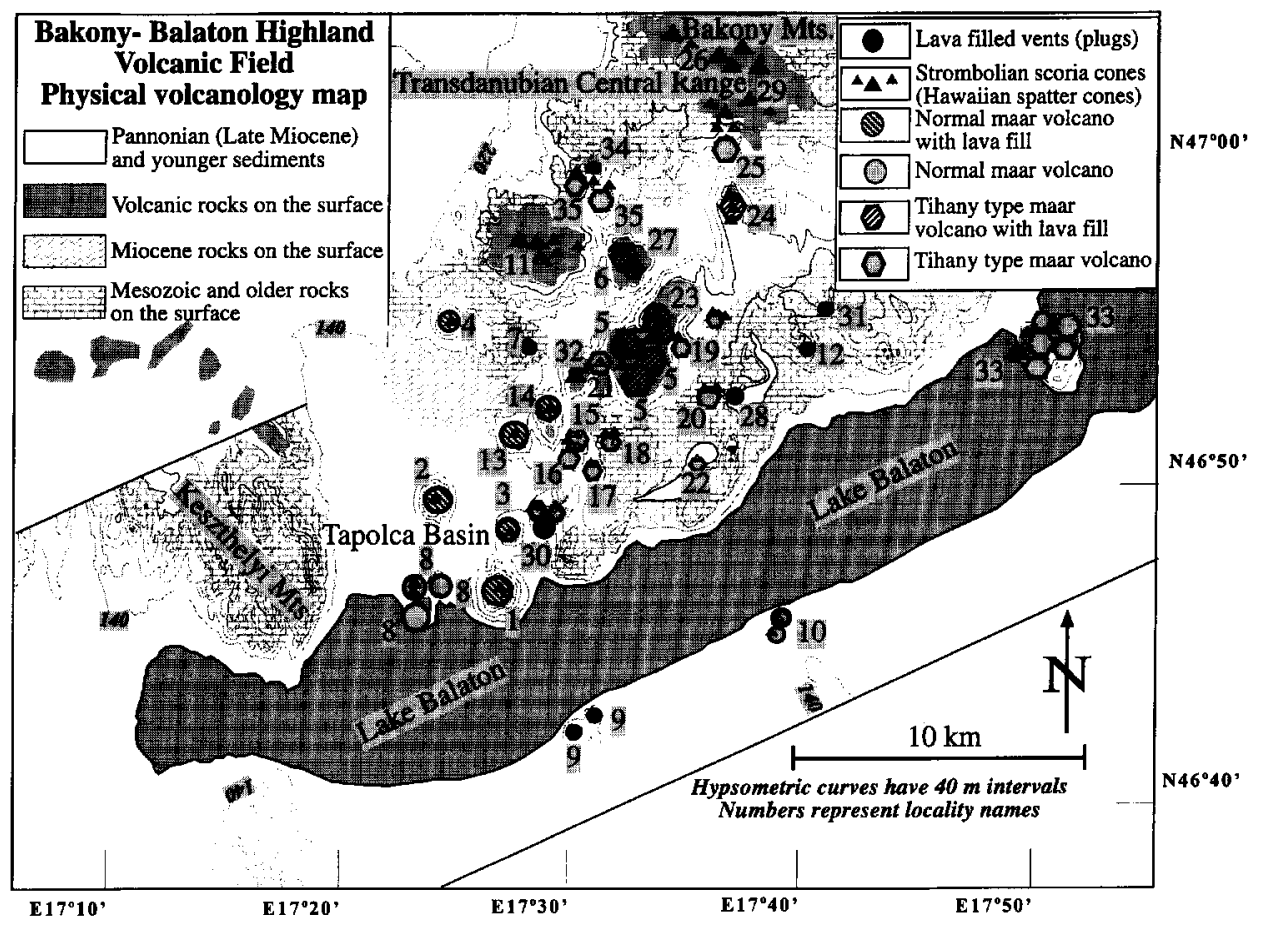

Fig. 2. Map with the classification of eruptive centres (with locality numbers shown on table 1-2-3).

ditions (term by KOKELAAR 1986) of volcanic evolution of individual volcanic edifices. The volcanism was related to the distribution of paleovalleys developed along ancient, probably rejuvenated pre-Neogene tectonic lines, similarly to processes in the West Eifel, Germany (BüCHEL 1993). After the volcanism, fluvial sedimentation was general in the area, but the recent Lake Balaton basin was filled just later, in the Quaternary (CSERNYI \& BODOR-NAGY 1997).

The explosive volcanic centers of the BBHVF show characteristics similar to the monogenetic basaltic volcanic fields in Arizona (Hopi Buttes) (WHITE 1991a, 1991b), Western Snake River, Idaho (Godchaux et al. 1992), Massif Central, France (JuvignÉ et al. 1993), Newer Volcanics, Victoria (JoYCE 1975, Johnson 1989), Eifel, Germany (SCHMINCKe 1977), Anatolia, Turkey (Keller 1973). The most widespread landforms are the circular, mostly lava capped buttes and hills of eroded maar crater fill sediment (fig. 3). These centers are usually related to underlying maar structures and occasionally eroded tuff ring rim remnants in areas where lavaflows preserved them. Individual maar structures without lava infill are less common, and hard to identify in the field. Their remnants consist of maar crater lake filling volcaniclastics. In the northern part of the BBHVF, Strombolian scoria cone remnants and Hawaiian spatter cone deposits are common, but usually individual Strombolian scoria beds, interbedded in hydrovolcanic setting, are also common everywhere in the field. There are large lava flows in the recently higher elevated areas in the Bakony Mountains. They 
are usually eroded pahoehoe type of flows with widespread columnar jointed structures. Small lavaflows in valley filling situation often occur (Hajagos-hegy). The largest lava covered areas in the Bakony Mountains are shield volcanoes (Kab-hegy; Agártetõ). Large lava plugs as eroded vent-filling lava forms occur together with adjacent vent-filling volcaniclastic sediments (Hegyestû).

It is claimed that the large volcanic centers always represent longer periods of volcanic activity with complex eruptive processes where mostly phreatomagmatic and magmatic phases alternated. Apparently there is little evidence of phreatic explosion processes. Usually late magmatic explosive and effusive processes followed the early phreatomagmatic processes.

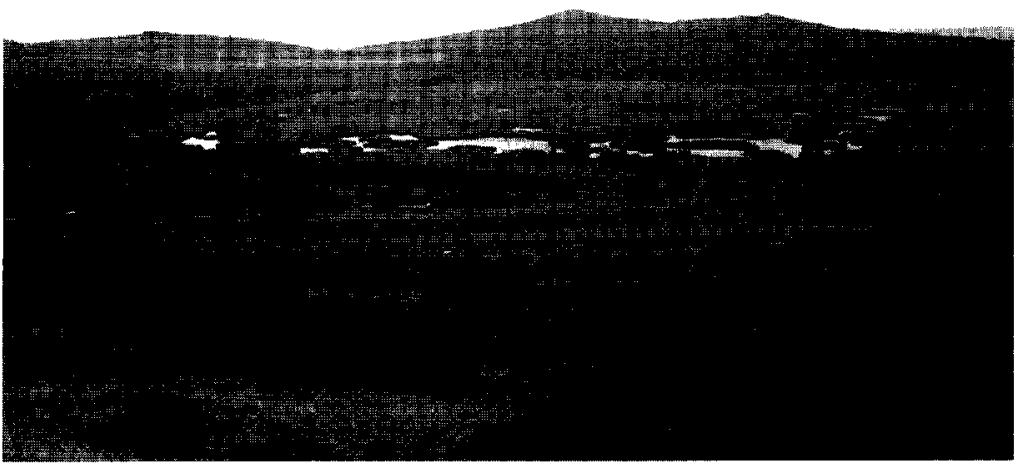

Fig. 3. General landscape of the BBHVF. View from east to west at Tihany.

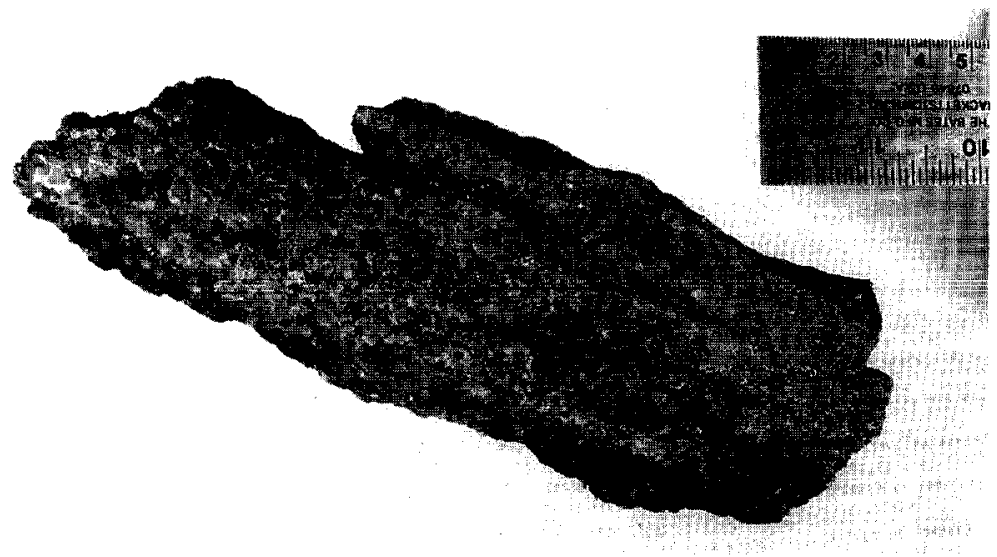

Fig. 4. Reworked tephra bed from maar lake deposit sequence (Tihany). Shorter side of the picture is $20 \mathrm{~cm}$. 
The recent geomorphology of the area shows intensive erosion and a geomorphic inversion during the last 7.54 Ma. The recent high elevated areas are usually lava capped steep sloped hills that represent former lava-filled maar craters. Former maar craters were often filled by reworked volcaniclastics (fig. 4) (tephra debris flow deposits, Gilbert-type deltaic rim deposits) and in the later stage by fine laminated freshwater carbonates which were strongly cemented by hot spring fluids (NÉMETH 1997, NÉMETH et al. in prep). These sequences also conserved the maar crater fill deposits to form butte structures. The remnants of the original Strombolian scoria cones usually are near vent agglutinates and spatter deposits. The original volcanic landform is strongly modified in the BBHVF by late erosional processes and only the crater fill or near vent sediments are traceable in recent time. In this paper a paleo-geomorphology reconstruction for the BBHVF is attemted at, calculating the relative pre-volcanic surface elevations to each volcanic centers according to their volcaniclastic sediments. Using the different type of volcaniclastic deposits so called negative and positive landforms as maar and scoria cones with lava lakes were identified and the position of the pre-volcanic surface to a certain age was recalculated.

Finally, two paleogeographic maps for the two possible age groups are shown.

\section{The hydromagmatic-magmatic spectrum from tuff cones to cinder cones}

Maar volcanoes which developed directly on fracture-controlled aquifer basement rocks (Mesozoic carbonate, Permian Red Sandstone, Silurian schist) or on thin Pannonian clastic sediments are excavated deeply in the underlying sequences, and produced mostly wet surge beds (term after e. g.: LoRENZ 1974, FrAZZETTA et al. 1983, 1989, Dellino et al. 1990, De Rosa et al. 1992) with a large amount of accidental lithics from depth. The other type of maar volcanic structures is developed, where the old fracture-controlled aquifers are covered by thick $(\sim 600 \mathrm{~m})$ Pannonian clastic sedimentary rocks (porous media aquifer). These maar volcanic structures produced dry surge deposits and almost in all cases the maar basins were filled by late magmatic explosive product as scoria and spatter beds with lava infill. Therefore, the relationship between the maar-related pyroclastic sequence and the nature of the underlying aquifer seems to be a very important factor to develop a different style of eruption and eruption products of the maar volcanoes on the BBHVF. Maars surrounded by "tuff-cone kind" (term by WOHLETZ \& SHERIDAN 1983) sequences of wet-surge deposits may be preferentially located in areas with underlying fracture controlled aquifers, covered by relatively thin (not more than $300 \mathrm{~m}$ ) porous media aquifers (Pannonian clastic sediments), that produce relatively high water yields to the explosion focus. Maars surrounded by "tuff-ring kind" sequences of dry-surge deposits, in contrast, correlate with underlying porous-media aquifers that produce relatively low water yields to the explosion focus. This situation is also possible in those areas where the fracture controlled aquifer is in a too deep position, thus the ongoing phreatomagmatic explosions are not able to excavate the maar basin deep enough to involve the fracture controlled aquifer to the phreatomagmatic explosions (Badacsony, Szentgyörgyhegy, Szigliget). In areas where tuffcone kind of deposits developed on top of porous-media aquifer, it is indicated that in some porous-media aquifers the flow rate of water into the vent may be as great 
as in fracture-controlled systems. Another possibility is that fracture-controlled aquifers may not be able to supply large amounts of water to the volcanic vent. This situation could happen if magma intrudes into an area of reduced permeability and hydraulic conductivity. Thus maar surrounded by a tuff ring may form, even if the explosion took place on fracture-controlled aquifer, which is virtually "empty" during the dry season, or if the magma fails to intercept a hydrologicaly important fracture within the rock mass. Therefore a cinder cone may form like in the BBHVF in regions where the fracture-controlled aquifer is relatively close to the surface. The fracture-controlled aquifer as pointed out could have a very strong seasonality due to the wide range of water supply by rainfall or spring run off. Thus it is possible that in areas where fracture-controlled aquifer was cut by rising magma produced large unusual type of maar volcanoes like Joya Honda in Mexico (ArandaGomez \& LUHR 1996) or in Tihany in the BBHVF (NÉMETH et al. in prep) in the wet season (spring vents), and few month later when the fracture-controlled aquifer is theoretically empty during the dry season, scoria cones developed due to lack of groundwater (summer vents).

\section{Complex volcaniclastic sedimentation in a fluvio-lacustrine basin}

The age distribution of the measured eruptive centers strongly varies (BALOGH et al. 1986) (fig. 1). There were two major problems with previous K/Ar age determination, sampling and loss of Ar. The samples for the age determination were collected from lavaflows that cover the previous volcaniclastic sequences. Therefore the age of the lavaflow not necessarly represents the age of the hydrovolcanic eruptive center. On the other hand close maar volcanic centers are able to collect lavaflows from different sources, thus the age determination from single samples can cause confusion. Weathering causes a significant Ar loss, a source of error in dating. The eruptive centers were grouped into different age groups to establish a geomorphic evolution. The ages from earlier database and the interpretations of the eruptive centers are shown on Table 1-2-3.

The position of the eruptive centers in the different age groups shows a slight westward shift of eruptive centers along a NE-SW line. The eruptive centers are situated in a gentle southward dipping paleosurface.

\section{$1^{\text {st }}$ age group}

The now higher elevated areas, covered by mostly magmatic explosive and effusive volcanic products suggest that the magma/water interaction in those areas was probably limited during the volcanism. Thus the Kab-hegy, and Agártetõ were already elevated hillside since $5.23 \mathrm{Ma}$, where the paleokarst surface was well below the paleosurface. In the lowlands the final Pannonian lacustrine sedimentation became of more fluvial character. Probably large flat alluvial plain formed in the early period of the volcanism, with small streams incised, swampy, small pond covered landscape. The oldest eruptive center in Tihany shows that in that time the hydrogeological conditions were good for maar forming, subaerial explosive activity. Tihany, a special type of maar volcanic complex formed (Tihany type maar volcano, by NÉMETH et al. in prep), where the thick karstwater bearing Mesozoic and Permian 


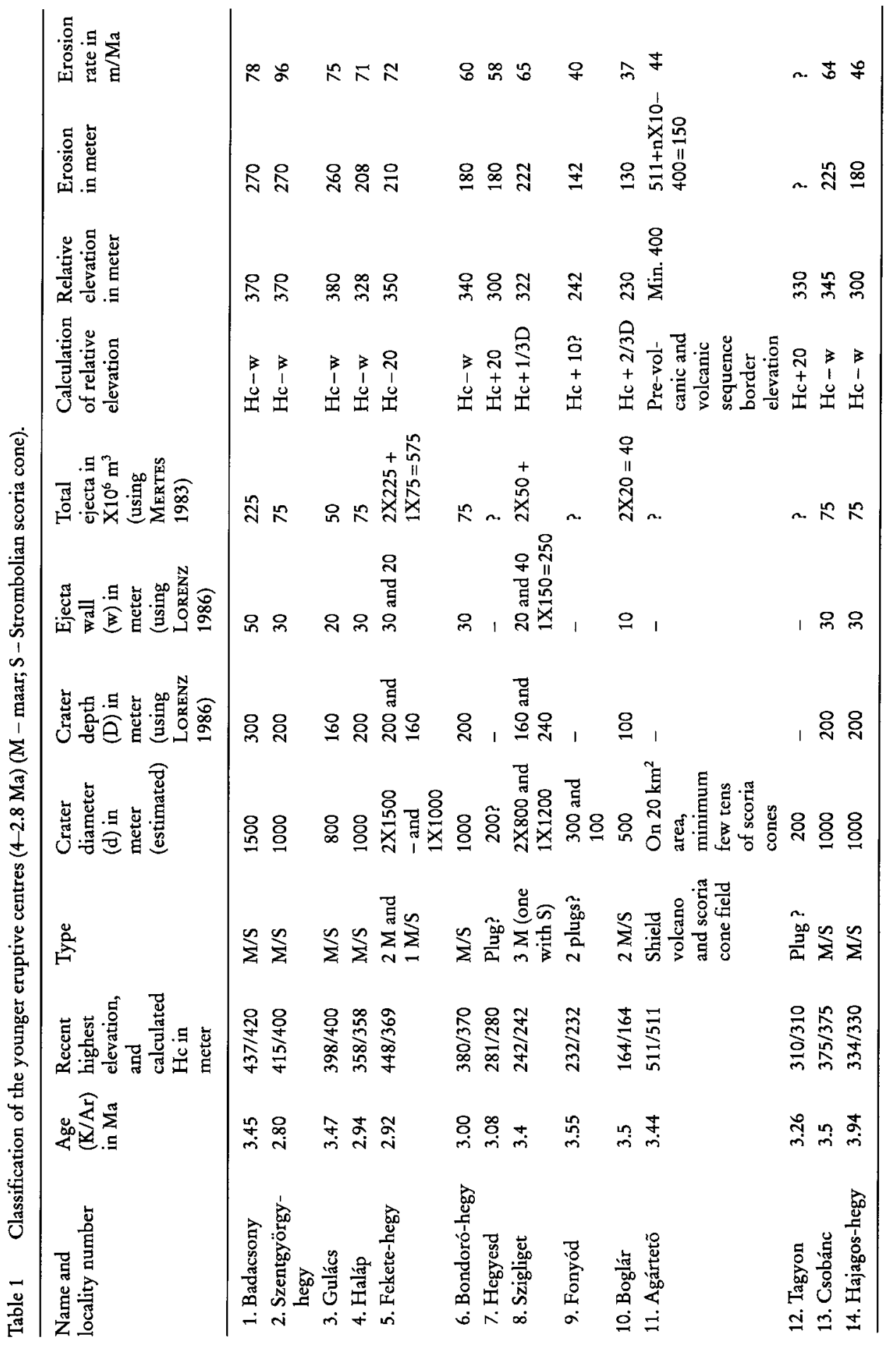




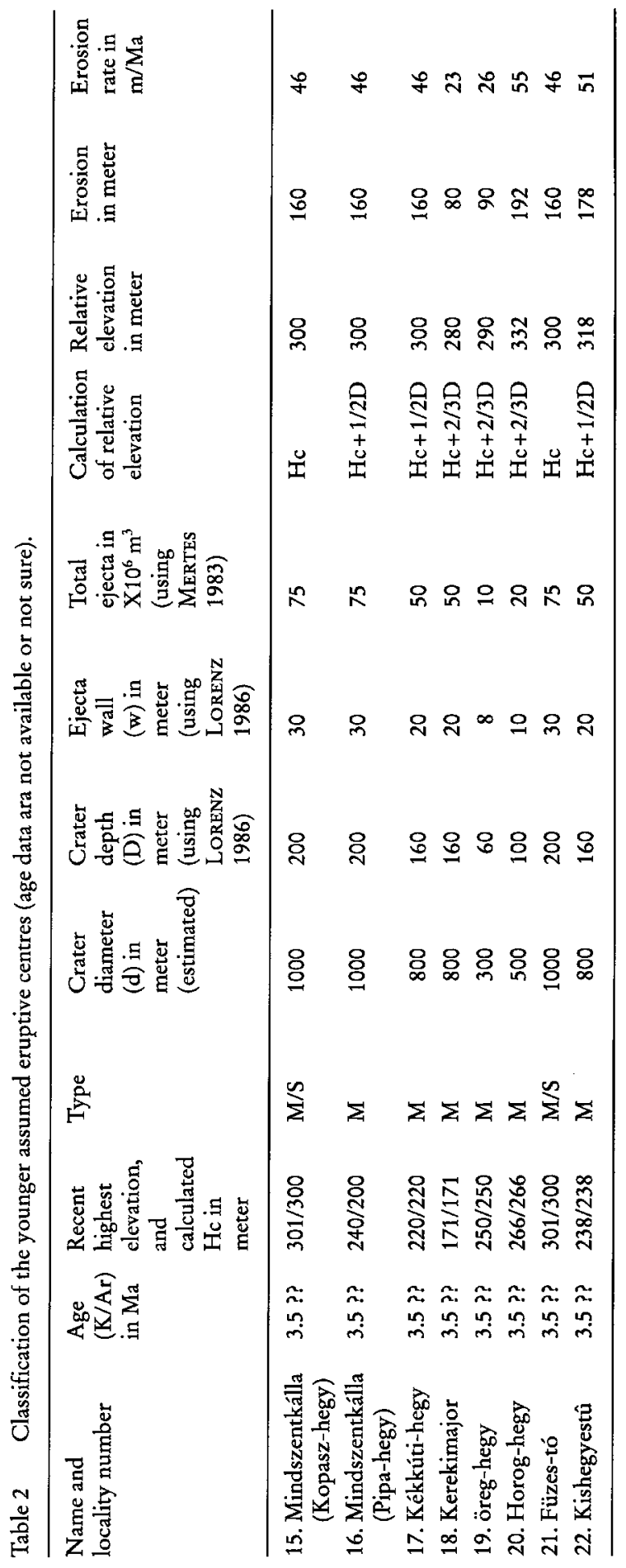




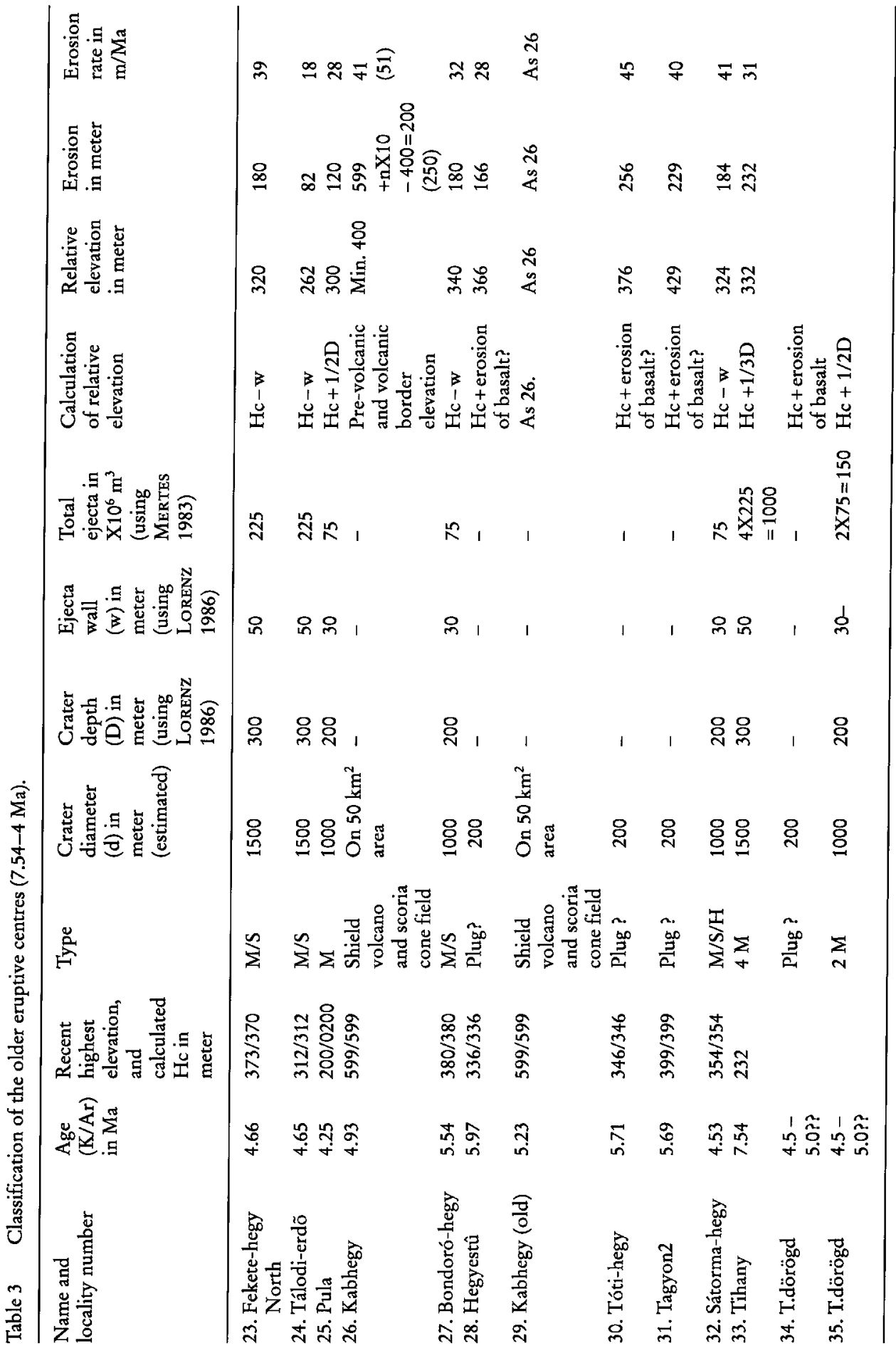


formations were covered by relatively thick Pannonian sand, which were intruded by uprising basaltic magma. In this case the individual eruptions were controlled by the water content of the wet Pannonian sand and the karstwater rich, fracturecontrolled aquifers. The formed maar craters were filled by debris transported by streams from the surrounding scoria cone fields. The individual maar craters functioned as local erosion bases (e.g. WHITE 1991a model). Gilbert-type deltaic fronts show NW to SE, N to $\mathrm{S}$ and NE to SW transportation direction. After the erosion of surrounding scoria field into the local erosion bases relatively quiet freshwater carbonate sedimentation started. The measured sedimentation rate in Tihany allowed 50000 year quiet undisturbed sedimentation in the maar lakes which were probably open to south.

\section{$2^{\text {nd }}$ age group}

The eruption centers of the second age group (6-5 Ma) show a westward shift from Tihany (fig. 1, fig. 2, Table 3). Kab-hegy represents "dry" conditions during volcanism (low water availability to fuel hydromagmatism), producing both explosive and effusive products and landforms. The other 3 localities (Tóti-hegy, Hegyestû, Mencshely) in the same age group probably represent feeder dykes. The Mencshely locality's stratigraphy is uncertain. Hegyestû contains a small amount of hyaloclastitic volcaniclastic adjacent to the main feeder system, suggesting that local water supply was available during the emplacement of the igneous body, but probably this was not enough to cause phreatomagmatic explosions. Tóti-hegy is a local feeder dyke. There are few samples from Holocene debris flanks from the nearby hills, which show hydromagmatic characteristics, but their relation to the plug (age and stratigraphy) is unknown. In this case there is a possibility that Tóti-hegy is a strongly eroded maar structure. The most complex center in this age group is Bondoró, with a hydromagmatic base, which suggests that the subsurface water supply was substantial in this lowland region. The distribution of eruptive centers of this age group shows a wide NE-SW zone, suggesting a wide alluvial fan area with relatively low relief.

\section{$3^{\text {rd }}$ age group}

The third age group (5-4 Ma) represents a more characteristic rows of eruptive centers from NE to SW (fig.1, fig. 2, Table 3). Kab-hegy was probably active over a longer period, thus built up a large shield volcanic edifice on the locally elevated Mesozoic block. The other three localities represent intensive hydromagmatic eruptive centers. The Pula eruptive center is a clear maar eroded remnant with alginite maar lake beds. Tálodi-erdõ is a maar complex with a thick lava cap. Fekete-hegy is a maar volcanic complex with several vents. All vents erupted thick lava flows, which filled the former maar basins. A lava flow closed the former stream valley between Feketehegy and Bondoró. This closed system could have caused overfilled maar lake development and local freshwater basin development in the Pula region. Boncsos-hegy represents a "drier" eruptive environment. The water content of the thinner Pannonian sand formation or the disrupted karstwater supply was able to change the eruptive style from phreatomagmatic to magmatic. 


\section{$4^{\text {th }}$ age group}

The eruptive centers of the fourth age group (4-2.8 Ma) show a more pronounced westward shift of the NE-SW trending line (fig. 1, fig. 2, Table 2-3). A shield volcano in the north was formed under "dry" eruptive conditions, representing little surface, subsurface water availability during its eruption. The Hajagos-hegy Gulács, Badacsony represent a large wide tuff ring structure with probably deep maar depression (according to the geophysical data), which were filled by thick (up to $50 \mathrm{~m}$ ) lava flows or lava lakes. The eruptive centers show a slightly N-S elongated form. Clearly visible, especially in the Hajagos-hegy, is a lavaflow which cuts through the former crater rim and flowed onto the pre-volcanic swampy area. These kinds of N-S, NE-SW elongated shape of individual centers strongly suggest that the volcanic center were exploded in an N-S; NE-SW streams valley system, where the original valley geometry controlled the morphology of the explosion craters. The N-S, NE-SW stream system occurrence is supported with presence of the widespread N to S Gilbert type deltaic systems in the area. These systems are clearly developed in the middle and western part of the BBHVF.

Clear subaqueous volcanic centers do not exist on the BBHVF. There is some evidence of emergent type of volcanism in the western-central part of the BBHVF. This is supported by samples of chilled, sideromelane rich lapilli, hyaloclastite from Holocene talus deposits around Hajagos-hegy and Kö-hegy. The strongly vitric character suggests a phreatomagmatic explosive activity. The initial volcaniclastic apron was built into a very shallow water mass (probably pond with less than $10 \mathrm{~m}$ depth), than the explosion focus downmigrated, causing normal maar forming explosions. The occurrence of relatively water rich surface in this regions is supported by the presents of the peperitic lava foot breccia, gas bubbles (tumuli) in the lower level of lava flows (Hajagos-hegy, Kõ-hegy, Gulács, Badacsony, Szigliget, Csobánc and Szentgyörgyhegy). In the Tapolca basin, the fracture-controlled aquifer was probably too deep during the volcanism thus normal tuff ring, maar forming volcanism developed. In the central part of the volcanic field the porous media aquifer was thinner, thus unusual type of maar volcanic centers, Tihany type maar volcanoes were built.

\section{Conclusion: paleogeographical reconstruction from physical volcanology data}

The age distribution and classification of different eruptive centres is shown on tables 1,2 and 3 . The eruptive centres are referred into two major age groups. The older one contains the centres, which are older than 4 million years. The younger group consist of centres with an age between 2.8 and 4 Ma. Figs. 8 and 9 show the two paleogeomorphological maps.

According to the physical volcanology observations with detailed mapping around the individual centers total erosion was estimated for each point. By identification of the volcaniclastic rocks and classification of each eruptive center according to their eruptive style, a geomorphological map could be drawn by age groups (fig. 6 and fig.7). The relative elevation term (Hp) was introduced which represents an elevation calculated on the base of physical volcanology data (fig. 7). We calculated relative elevation data for the previously separated two age groups to create a paleo- 
geomorphological map. Fig. 6 summarizes the basic terminology to separate different volcaniclastic units related to maar/diatreme volcanism. The terminology is based on WHITE (1991b), elaborated to describe different levels of eruptive center erosion remnants from the Hopi Buttes (fig. 6).

The major eruptive centers with large Bouguer anomaly, geomagnetic anomaly and occurrence of primary phreatomagmatic and reworked maar crater fill sediments reconstructed as large maar structures which were depressions. In areas where mostly magmatic volcaniclastics were found and no Bouguer anomaly was reported, elevations were reconstructed compare to the pre-volcanic surface.

Where large lava capped buttes are above large Bouguer anomaly areas and phreatomagmatic deposits are found, the eruptive centers have a deep excavated maar basement. The measured diameter of the recent remnant of the lava filled maar basin is almost equal to the real maar basin diameter (d) since the crater wall of the maar basin is very steep (fig. 6 and fig. 7). From the measured/estimated crater diameter (d) we calculate the maximum crater depth (D) according to LORENZ (1986) empirical form $(D=d / 5)$, based on statistical studies of relatively young maars. The total ejecta from individual centers was calculated using the empirical diagram of MERTES (1983). Tables 1-2-3 show the calculated values for each studied eruptive centers. Fig. 7 shows the 3 main basic situation to calculate the relative elevation of the pre-eruptive surface. The three basic type are:

1 - maar basin filled by late magmatic upper diatreme structure (scoria cones, lava lakes) then eroded to different levels;

2 - maar basins developed and filled by late reworked tephra deposits, fresh water carbonates, then eroded to different levels;

3 -scoria cones, shield volcanoes, commonly with lava lakes, spatter cones developed then eroded.

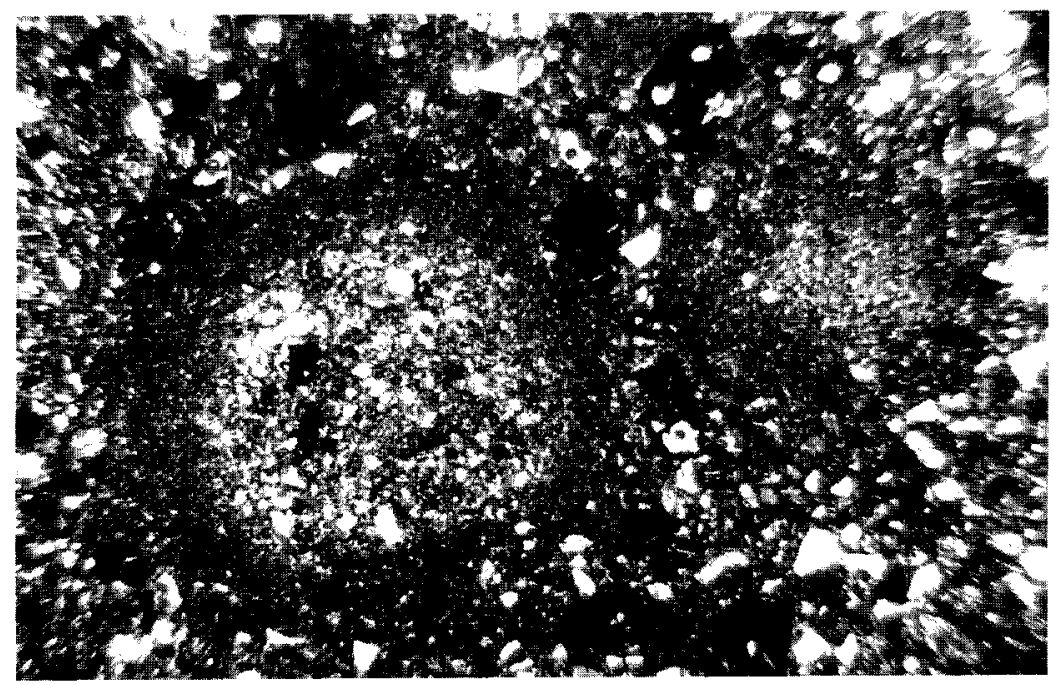

Fig. 5. Primary volcaniclastic sediment in thin section with rim-type accretionary lapilli (Bondoró). Shorter side of the picture is $2 \mathrm{~mm}$. 


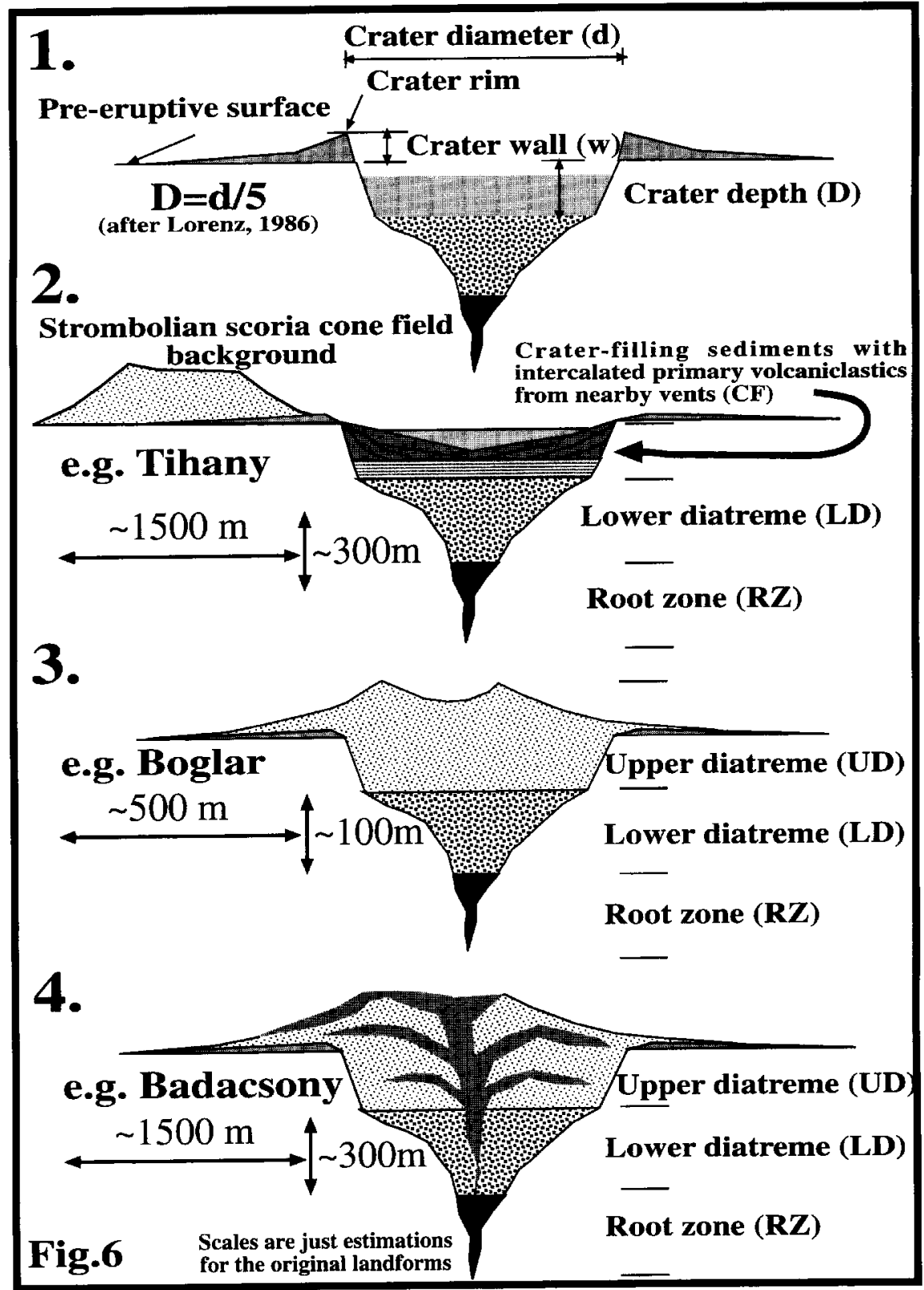

Fig. 6. Terminology of maar/diatreme landforms, sedimentary units. 


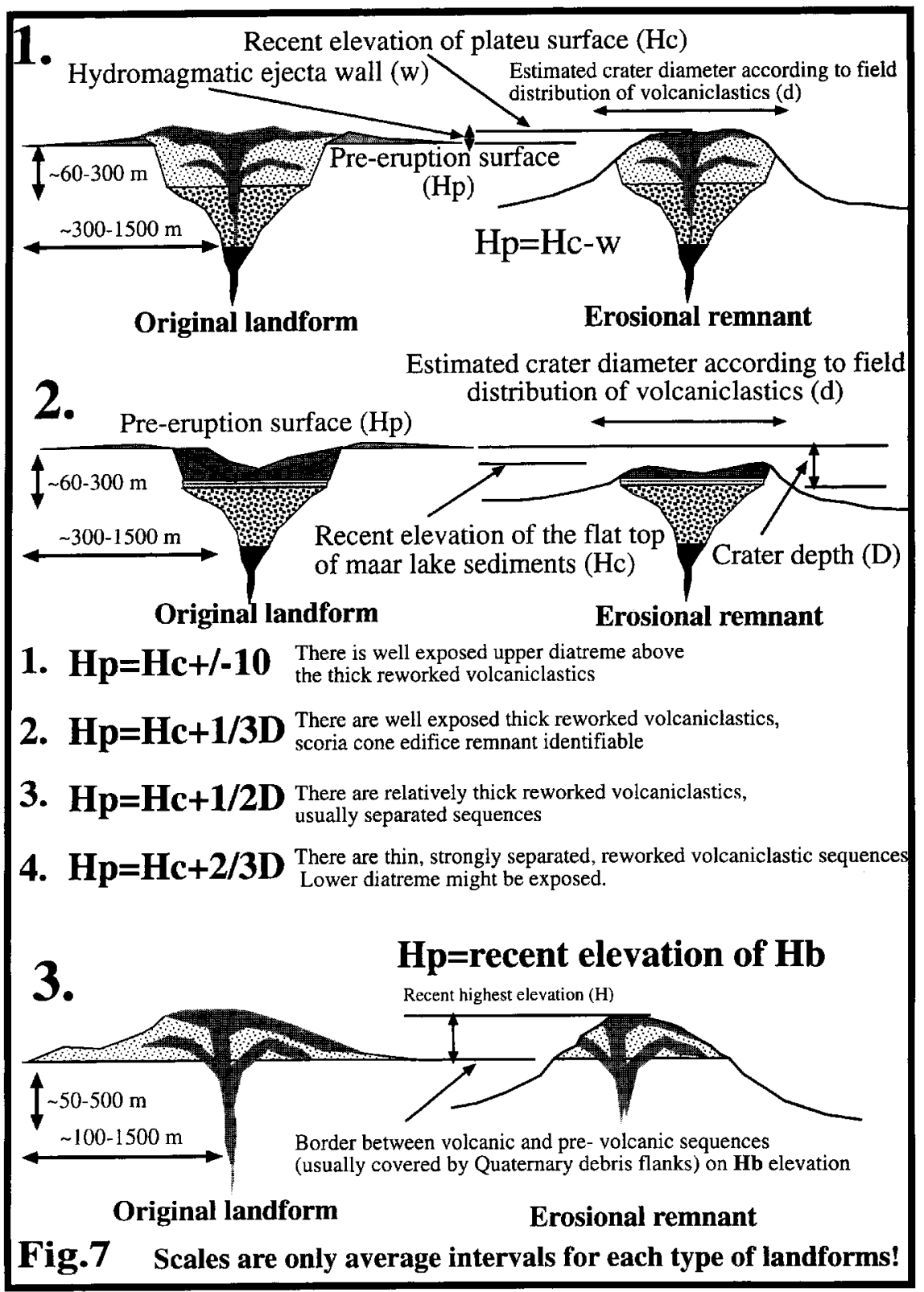

Fig. 7. Calculation of relative elevation (pre-volcanic surface elevation), for explanation see the text. 
The first situation (fig. 7/1) shows those centers with a thick lava cap with underlying maar basin. The lava cap is above Strombolian scoria beds. The symmetric shape of the buttes allowed us to estimate that the upper diatreme were built into a former maar basin, thus the size and shape of the lava lake were controlled by the ejecta wall (w). Therefore $\mathrm{Hp}=\mathrm{Hc}-\mathrm{w}$. $\mathrm{Hc}$ is the recent plateau surface on the top of the buttes. Introducing $\mathrm{Hc}$ is important because several irregularities on the top of the buttes are related with former vent filled zones, even plugs, thus they were probably positive forms compare to the top of the ejecta walls. For the ejecta wall estimation observations and descriptions by e.g. Wohletz \& Sheridan (1983), Fisher \& SCHMINCKe (1984), LORENZ (1986), WHITE (1991), BüCHEL (1993) were used for the geometrical parameter of thickness of crater rim deposits, which range from a few tens of meters to 200 meters. Basically the crater rim deposit thickness is strongly controlled by the geometrical size of the maar crater, thus estimated to ca $50-100 \mathrm{~m}$.

Fig. $7 / 2$ provides a model for maar basin development, later filled by reworked tephra deposits. The calculation of the erosion in this case is strongly dependent on the calculated crater depth (D). The crater depth has been calculated after Lorenz (1986) measuring and estimating the crater diameter (d). Depending on the facies distribution around the maar complexes, erosion has been calculated by adding the relative amount of eroded material to the measured recent plateau elevation of volcaniclastics $( \pm 10 ; 1 / 3 \mathrm{D} ; 1 / 2 \mathrm{D} ; 2 / 3 \mathrm{D})$. Most of the BBHVF this type of eruptive centers are remnants of the case of fig. $7 / 2-2$ and fig. $7 / 2-3$. Each case is demonstrated in fig. 8 .

The calculation of the prevolcanic surface elevation of landforms like spatter cones, scoria cones and shield volcanoes without maar base are shown in fig.7/3.

The two paleogeomorphology maps (fig. 9 and fig. 10) indicate that volcanism was strongly controlled by the distribution of Pannonian sediments, the general geomorphology of the area, deep structures in the basement, and the syn-volcanic karst water level.

To summarize the geomorphological evolution of the BBHVF, volcanism was found to occur in a fluvio-lacustrine basin. The early eruptions formed in the south eastern side of the field, where the former lacustrine sedimentation turned into a fluvial environment. In this region the former lacustrine sediments were still water saturated and unconsolidated. The thin porous media aquifer and the thick fracturecontrolled aquifer ensured a substantial water supply to fuel hydromagmatic explosive volcanism producing unusual maar structures. During the next stage alluvial fans developed by streams coming from the slightly higher background, the Late Miocene hills of Bakony Mts. Finally explosive and effusive volcanism occurred in the swamps, streams and small ponds. The largest volcanic complexes (Fekete-hegy, Bondoró-hegy) erupted large, long lavaflows which probably blocked the slightly higher elevated areas around the Tálodi-erdõ, Pula region, thus the run off waters from the background (Bakony Mts.) formed a large post-volcanic freshwater lake. Finally volcanism shifted westward, following the same NE-SW line. These volcanic centers are of slightly emergent character, but the major part of them are tuff ring, maar type of subaeral volcanic center.

The phreatomagmatic volcanic centers show fine, linear distribution, suggesting that longitudinal stream occupied valleys occurred at this time. The elongated structure also suggests a deep fracture system in the fracture-controlled aquifer, which 

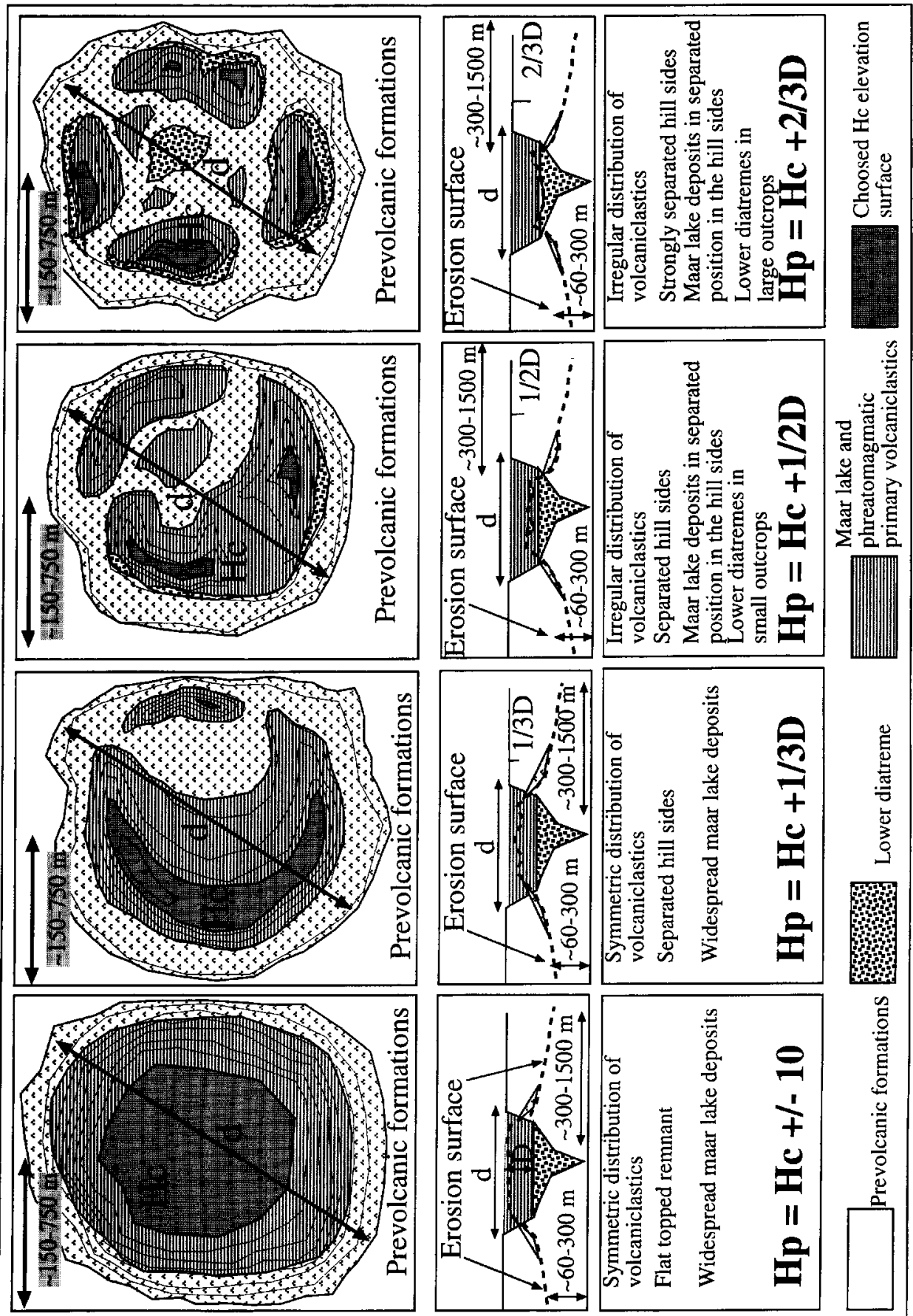

Fig. 8. Calculation of pre-eruptive surface elevation for maar basins without lava caps. 


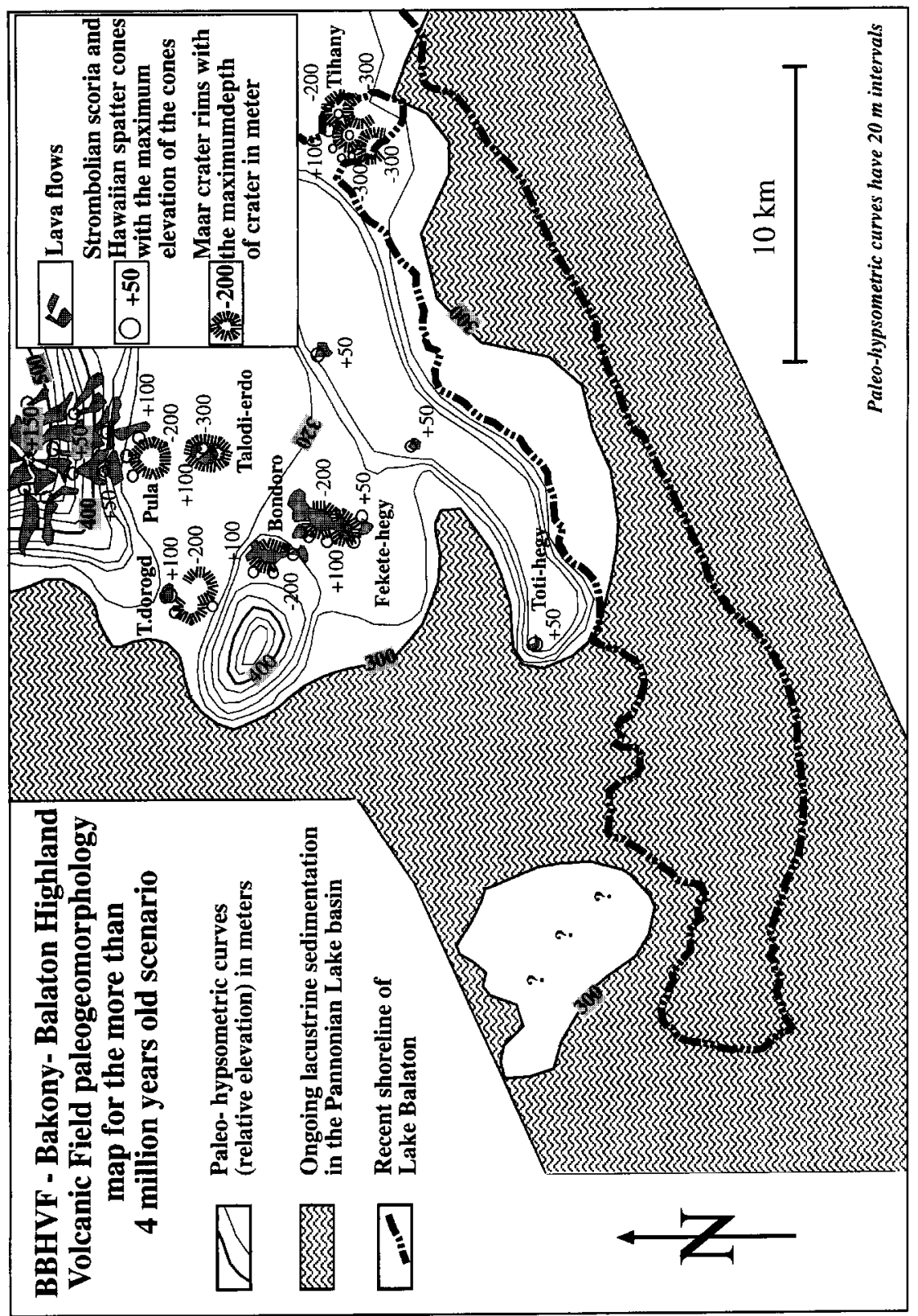

Fig. 9. Paleogeography map for the more than 4 million years scenario $(7.54-4 \mathrm{Ma})$. 


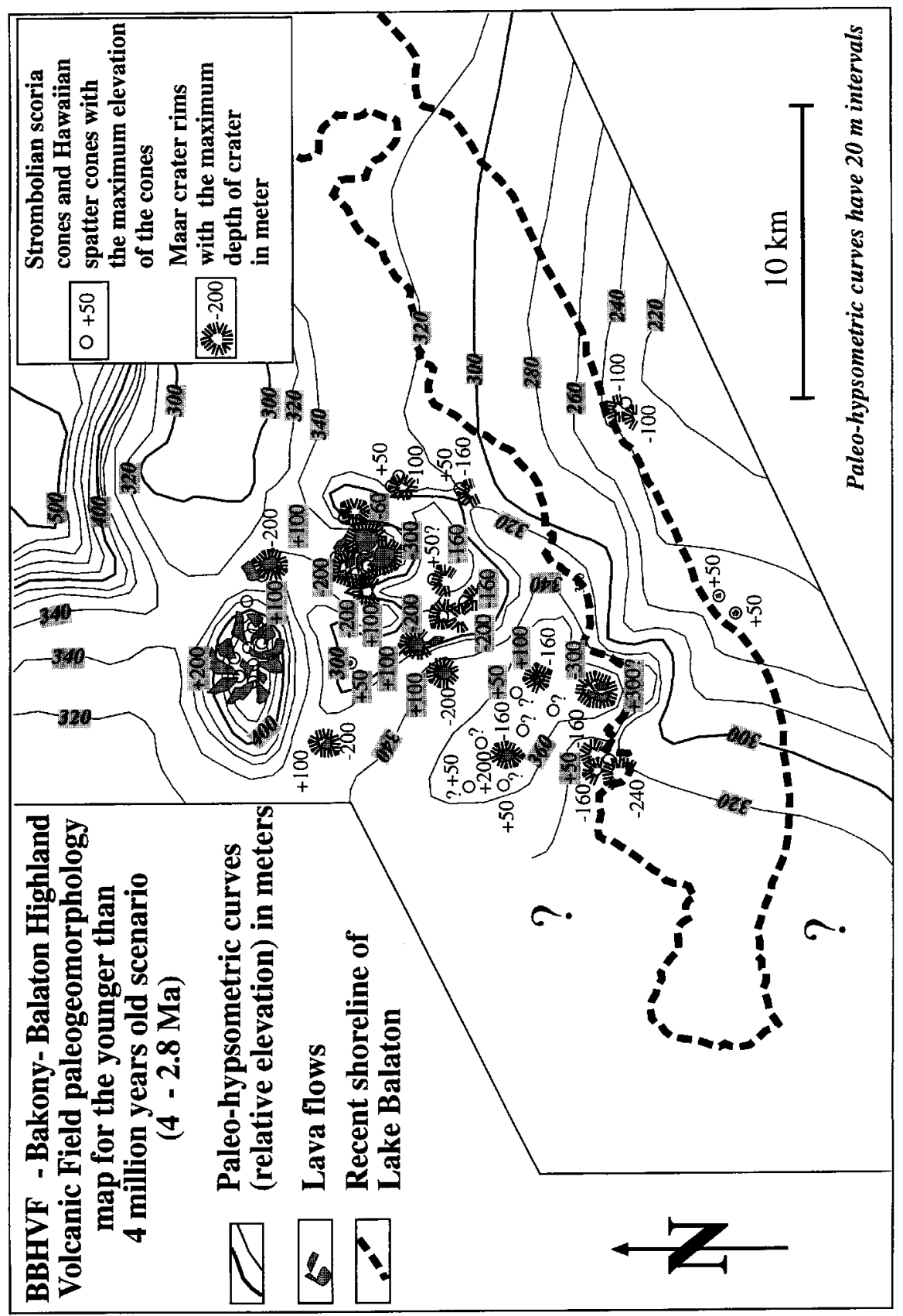

Fig. 10. Paleogeography map for the 4-2.8 million years scenario. 
allowed free water movement of the subsurface karst water, thus able to fuel phreatomagmatic explosions. The fractures were also able to control the path of the uprising basaltic melt. These two major controls operated together parallelly. The lacustrine environment (Pannonian Lake) was replaced by separate lake basins controlled the water content of the porous media aquifer. The most enduring sub-basins are responsible for hydromagmatic explosions in later time. The focus of volcanism shifted to the western Tapolca Basin, where thick water-saturated, mostly lacustrine sediments occurred.

The calculated erosion rate of the individual centers varies between $96 \mathrm{~m} / \mathrm{Ma}$ (Szentgyörgy-hegy) to $18 \mathrm{~m} / \mathrm{Ma}$ (Tálodi-erdõ). In the highlands the erosion rate of the shield volcanoes is not more than $51 \mathrm{~m} / \mathrm{Ma}$. The erosion rate in the BBHVF is relatively high in comparison to other basaltic monogenetic volcanic fields but is in the same range $(\sim 30 \mathrm{~m} / \mathrm{Ma})$ as the Miocene to Quaternary andesite/dacite stratovolcanoes in the Carpathians in Romania, Slovakia and Hungary (KARÁtson 1996, 1999, Karátson et al. 1999). In southern Australia, a relatively low elevated volcanic field (the prevolcanic surface is $100-200 \mathrm{~m}$ above sea level), on a mild climate showed $8 \mathrm{~m} / \mathrm{Ma}$ erosion rate (WELLMAN 1979, Bishop 1985). WALKER (1984) calculated downcutting rates of $58 \mathrm{~m} / \mathrm{Ma}$ in the elevated basaltic highlands of Iceland in the region where the mean elevation is $400 \mathrm{~m}$. According to authors' calculation a strong uplift process is assumed for the last few million of years accompanied with a cold, sub-arctic weather. Probably the uplift was penecontemporaneous with the volcanism. The erosion rate was probably effected by the later developed fluvial systems, which cut through the region, eroded the uncovered volcanics and the erodable Pannonian lacustrine and fluvial beds.

\section{Acknowledgement}

Thanks are due to James D. L. White (University of Otago, Dunedin, Geology Department) for the great discussions about phreatomagmatism, Csaba Szabó (Eötvös University, Budapest, Department of Petrology and Geochemistry) for the help in understanding the mantle processes beneath the BBHVF and Gábor Csillag (Geological Institute of Hungary, Budapest) for valuable fieldwork and understanding the prevolcanic stratigraphy. Thanks are also due to Jean-Baptiste Rosseel (University of Otago, Geology Department) for the French translation of the abstract. Two anonymos reviewers helped to improve the manuscript.

\section{References}

Aranda-Gomez, J.J. \& J.F. Luhr (1996): Origin of the Joya Honda maar, San Luis Potosi, México. - J. Volc. Geotherm. Res. 74: 1-18.

BALLANCE, P.F. \& I. E. M. SMITH (1982): Walks through Auckland's geological past: a guide to the geological formations of Rangitoto, Motutapu and Motiuhe Islands. - Geol. Soc. New Zealand - Guidebook 5.

BALOGH, K. (1995): K/Ar study of the Tihany Volcano, Balaton Highland, Hungary. Report on the work supported by the European Community in the frame of program "Integrated Basin Studies”.- Institute of Nuclear Research, Hungarian Academy of Sciences, Debrecen, p. 1-12. 
Balogh, K., Arva-Sós, E. \& Z. Pécskay (1986): K/Ar dating of post-Sarmatian alkali basaltic rocks in Hungary. - Acta Miner. Petrol., Szeged 28: 75-93.

Balogh, K, A. Jámbor, Zs. Partényi, L. Ravaszné Baranyai \& G. Solti (1982): A dunantúli bazaltok $\mathrm{K} / \mathrm{Ar}$ radiometrikus kora (K/Ar radiometric age of basalts from Transdanubia). - MÁFI. Jel. 1980: 243-260 (in Hungarian).

Brshop, P. (1985): Southeast Australian late Mesozoic and Cenozoic denudation rates: a test for late Tertiary increases in continental denudation. - Geology 13: 479-482.

Borsy, Z, K. BALOGH, M. KoZÁK \& Z. PÉcsKAY (1986): Újabb adatok a Tapolcai-medence fejlõdéstörténetéhez (New data to the evolution of Tapolca Basin). Acta Geogr. Debrecina 23: 79-104 (in Hungarian).

Büchel, G. (1993): Maars of the Westeifel, Germany. - In: J. F. NEgENDANK, \& B. ZolitschKA (eds.): "Lecture notes in Earth Sciences" 49: Paleolimnology of European Maar Lakes, Springer-Verlag, Berlin, Heidelberg.

CsERNY, T. \& E. NAGY-BoDor (1997): The pre-Quaternary morphology and Quaternary geohistory of Lake Balaton. - Z. Geomorph. Suppl. NF: 110: 137-144.

Delino, P., G. Frazzetta \& L. La Volpe (1990): Wet surge deposits at la Fossa di Vulcano: depositional and eruptive mechanism. - J. Volc. and Geotherm. Res. 43: 215-233.

De Rosa, R., G. FrazzetTA \& L. LA VOLPE (1992): An approach for investigating the depositional mechanism of fine-grained surge deposits. The example of the dry surge deposits at "La Fossa di Vulcano". - J. Volc. and Geotherm. Res. 51: 305-321.

Fisher, R. V. \& H.-U. Schmincke (1984): Pyroclastic rocks. - Springer Berlin-HeidelbergNew York, 472 pp.

FrazzetTa, G., L. LA Volpe \& M. F. Sheridan (1983): Evolution of the Fossa cone, Vulcano.J. Volc. and Geotherm. Res. 17: 329-360.

- (1989): Interpretation of emplacement units in recent surge deposits on Lipari, Italy. - J. Volc. and Geotherm. Res. 37: 339-350.

Godchaux, M. M., B. Bonnichsen \& M.D.Jenks (1992): Types of phreatomagmatic volcanoes in the western Snake River Plain, Idaho, USA. - J. Volcanol. Geotherm. Res. 52: 1-25.

JÁmbor, A., Zs. PART'́ny \& G. SOlti (1981): A dunantúli bazaltvulkanitok földtani jellegei (Geological characteristics of the basaltic volcanic rocks from the Transdanubian region). - MÁFI Jel. 1979, p. 225-239 (in Hungarian).

Johnson, R.W. (ed.) (1989): Intraplate volcanism in Eastern Australia and New Zealand. Cambridge University Press, 408 pp.

JoYCE, E. B.(1975): Quaternary volcanism and tectonics in southeastern Australia. - In: SugGATE, R. P. \& M. M. CRESSWEll (eds.): Quaternary Studies. Royal Society of New Zealand, Bulletin 13: 169-176.

Jugovics, L. (1968): A Balatonfelvidék és a Tapolcai medence bazaltvidékének földtani jellegei (Geological characteristics of the basalt lands of the Balaton Highland and the Tapolca Basin). - MÁFI Jel., 1968, p. 223-243 (in Hungarian).

Juvigné, E., G. Camus \& A. Goer de Herve (1993): Maars of northern Auvergne (Massif Central, France): state of knowledge. - In: J.F. Negendank \& B.Zolitschka (eds.): Lecture notes in Earth Sciences 49: Paleolimnology of European Maar Lakes, SpringerVerlag, Berlin, Heidelberg, p. 81-94.

KARÁTSON, D. (1996): Rates and factors of stratovolcano degradation in a continental climate: a complex morphometric analysis of 19 Neogene/Pleistocene crater remnants in the Carpathians. - J. Volcanol. Geotherm. Res. 73: 65-78.

- (1999a): Erosion of primary volcanic depressions in the Inner Carpathian Volcanic Chain. - Z. Geomorph. Suppl. N. F. 114: 49-62.

Karàtson, D., J.-C. Thouret, I. Moriya \& A. Lomoschitz (1999): Erosion calderas: origins, processes, structural and climatic control. - Bull. Volcanol. 61: 174-193.

KÁzmér, M. (1990): Birth, life, and death of the Pannonian Lake. - Paleogeogr. Paleoclimat. Paleoecol. 79: 171-188. 
KeLLER, J. (1973): Quaternary maar volcanism near Karapinar in Central Anatolia. - Bull. Volcanol., p. 378-396.

KOKELAAR, P. (1986): Magma-water interactions in subaqueous and emergent basaltic volcanism. - Bull.Volcanol. 48: 275-289.

Lelkes-Felvári, Gy. (1978): Petrographische Untersuchung einiger prepermischer Bildungen der Balaton-Linie. - Geol. Hung. Ser. Geol. 18: 224-295.

Lóczy, L. (1913): A Balaton környékének geológiai képzõdményei és ezeknek vidékek szerinti telepedése (Geological features around the Lake Balaton and their stratigraphy). Balaton Tud. Tan. Eredm. I., in Hungarian.

LORENZ, V. (1974): Vesiculated tuffs and associated features. - Sedimentology 21: 273-291.

- (1986): On the growth of maars and diatremes and its relevance to the formation of tuff rings. - Bull. Volcanol. 48: 265-274.

Majoros, Gy. (1980): Problems of Permian sedimentation in the Transdanubian Central Mountains: a palaeogeographic model and some conclusions. - Földtani Közlöny 110: 323-341. [in Hungarian with English abstract].

Mertes, H. (1983): Aufbau und Genese des Westeifeler Vulkanfeldes. - Bochumer Geol. und Geotechn. Arb. 9: 1-415.

NÉmETH, K. (1997): A complex phreatomagmatic volcano in the Pannonian Basin (Tihany Paleovolcano, Hungary). - Z. Geomorph. N. F. Suppl. 110: 145-157.

Németh, K., U. Martin \& Sz. Harangi (1999): Miocene hydrovolcanism in the Central Pannonian Basin, Hungary: evolution of the Tihany Volcano as a new type of maar volcano. Bull.Volcanol. (submitted).

Schmincke, H.-U. (1977): Phreatomagmatische Phasen in quartaren Vulkanen der Osteifel. Geol. Jahrbuch 39: 3-45.

Szabó, Cs, Sz. Harangi \& L. Csontos (1992) Review of Neogene and Quaternary volcanism of the Carpathian-Pannonian Region - In: ZIEGLER P. A. (ed.): Geodynamics of rifting. Vol. 1. Case studies on rifts: Europe and Asia. Tectonophysics 208: 243-256.

TARI, G. (1994): Alpine tectonics of the Pannonian basin. - [PhD Thesis]: Rice University, Houston, 501 pp.

WALKER, G.P.L. (1984): Characteristics of dune bedded pyroclastic surge bedsets. - J. Volc. Geotherm. Res. 20: 281-296.

Wellman, H.W.(1979): An uplift map for the South Island of New Zealand and a model for uplift of the Southern Alps. - In: WalcotT, R. I. \& M. M. CResswell (eds.): The origin of the Southern Alps, Royal Society of New Zealand Bull. 18: 13-20.

WHITE, J.D. L. (1991a): The depositional record of small, monogenetic volcanoes within terrestial basins. Sedimentation in Volcanic Settings. - SEPM Spec. Publ. 45: 155-171.

- (1991b): Maar-diatreme phreatomagmatism at Hopi Buttes, Navajo Nation (Arizona), USA. - Bull. Volcanol. 53: 239-258.

WOHLETZ, K. H. \& M. F. SHERIDAN (1983): Hydrovolcanic explosions II. Evolution of basaltic tuff rings and tuff cones. - Am. J. Sci. 283: 385-413.

Address of the authors: University of Otago, Geology Department, P.O. Box 56., Dunedin, New Zealand. E-mail: nemeth_karoly@hotmail.com and uli_martin@hotmail.com 
Late Miocene paleo-geomorphology of the Bakony-Balaton Highland Volcanic Field (Hungary) using physical volcanology data

Nemeth, Karoly

1999-01-01

http://hdl.handle.net/10179/9631

22/04/2023 - Downloaded from MASSEY RESEARCH ONLINE 